\begin{tabular}{llllllllllllllllllllllllllll}
\hline A & C & T & A & A & R & C & H & A & E & O & L & O & G & I & C & A & C & A & R & P & A & T & H & I & C & A
\end{tabular}

\begin{tabular}{lr} 
VOL. LV (2020): 235-254 & PL ISSN 0001-5229 \\
\hline
\end{tabular}

DOI 10.4467/00015229AAC.20.010.13515

\author{
Magdalena Okońska-Bulas, Jan Bulas, ${ }^{(0)}$ MirosŁaw MazureK, \\ Aldona Garbacz-Klempka, Mazgorzata Perek-NowaK ${ }^{\circledR}$
}

\title{
A NEWLY Discovered FRAGMENT OF A HUNNIC CAULdRON From Site 59-60, Sanok, Poland
}

\begin{abstract}
The article presents a newly discovered fragment of the Hunnic cauldron, unearthed during investment research conducted at site 59-60 in Sanok, Sanok County, Podkarpackie Voivodeship. As a result of conducted excavations, an extensive settlement from the Late Roman Period and the Early Migration Period were discovered. The fragment of the cauldron in one of the most important discoveries from here. Up to date just over 20 specimens of cauldrons or their fragments are known from Central Europe. The presented one is just the second cauldron discovered in the area of Poland. The article contains the results of stylistic, typological and chemical analyzes confirming the interpretation of this find.
\end{abstract}

Keywords: Hun period, hunnic cauldron, SEM-EDS, Upper San Basin, XRF

In 2017-2018, a rescue excavation was carried out at multicomponent archaeological site No. 59-60, Sanok, Sanok County, Podkarpackie Voivodeship, in connection with a land development project ${ }^{1}$, with a total area of more than 5 ha uncovered (see Fig 1. Map). The site is located on the eastern slope of a gentle hill with a maximum elevation of $340.8 \mathrm{~m}$ above sea level, in the valley of a small stream. The site holds a settlement complex, parts of which were excavated, revealing 6 phases of ancient occupancy, including a Lusatian culture settlement in upper strata and a multi-hectare Roman and Early Migration Period settlement, which was occupied from ca. mid- $3^{\text {rd }}$ to the first half of the $5^{\text {th }} \mathrm{c}$. AD. The latter covered the central and eastern part of the excavated area

${ }^{1}$ The rescue excavation project was undertaken in advance of the construction of the ring road of Sanok, part of the Zator-Medyka section of national road No. 28. It was financed by the General Directorate for National Roads and Motorways (Pol. GDDKiA - Generalna Dyrekcja Dróg Krajowych i Autostrad) and carried out by the trust Fundacja Rzeszowskiego Ośrodka Archeologicznego under the leadership of Mirosław Mazurek and Konrad Drewniak.

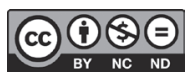



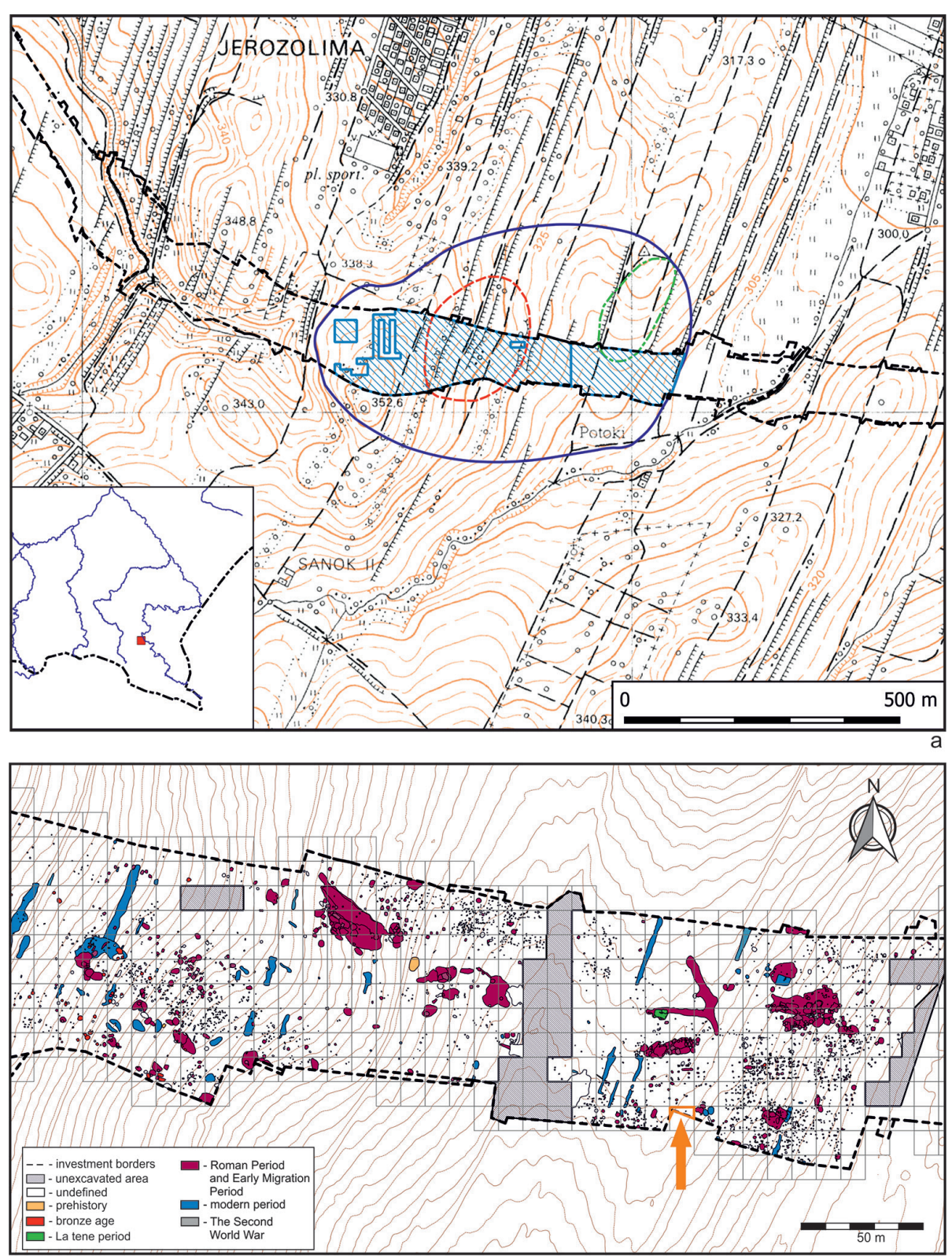

b

Fig. 1. a - Location of road lane, excavation borders and range of sites according to Polish Archaeological Record (the red line - Sanok, Sanok County, site 59, the green line - Sanok, Sanok County, site 60, the blue line - preasumably range of the multicultural settlement); b - Fragment of the plan of the site Sanok, site 59-60, close-up on excavated part dated to of the Roman period and Early Migration period 
and was located on the lower slope, i.e. below $325 \mathrm{~m}$ above sea level. Within the settlement, more than 1800 various Younger and Late Roman Period, and Early Migration Period features were unearthed including, among others, post holes, more than 100 rectangular hearths, 2 pottery kilns and 4 wells (Bulas et al. 2019). The rescue archaeology project at site No. 59-60 in Sanok yielded abundant data on Late Roman and Early Migration Period settlement in the upper San River basin, including on the layout of settlement sites dated to that period ${ }^{2}$.

One of the most important finds among the many artefacts discovered at the Sanok settlement site is a fragment of a bronze item, which has been interpreted to be a broken-off piece of a Hunnic cauldron (Fig. 2). It is a stray find, discovered without an archaeological context located among Roman Period features (Fig. 1), by the southern border of the excavation area.

Hunnic cauldrons or their fragments are rare finds. To date, a total of slightly more than 20 specimens, including fragments, have been discovered in Eastern Europe, of which only 1 was found in Poland (Fig. 3; Masek 2017, see Fig. 25, 120, Catalogue). A very particular category of artefacts, Hunnic cauldrons have over the years inspired numerous in-depth studies dedicated to their characteristics, origins, chronology, and use (Nestor, Nicolăescu-Plopşor 1937; Meanchen-Helfen 1973, 306-337; Harhoiu, Diaconescu 1984; Zaseckaja, Bokovenko 1994; Kovrig 1972; Harhoiu 1997; Anke 1998; Tejral 2000; Koch 2007; Masek 2017).
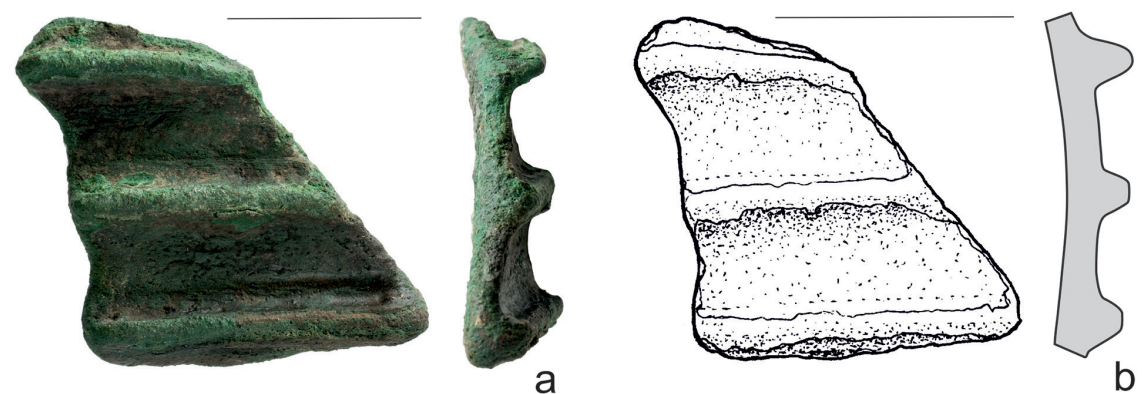

a

b

\section{$5 \mathrm{~cm}$}

Fig. 2. Sanok, Sanok County, site 59-60. The discovered piece of the Hunnic cauldron

2 During the archaeological works on the same investment project, second multiphase settlement in Sanok (site 42) was excavated. The research was lead by the Fundacja Rzeszowskiego Ośrodka Archeologicznego. The leader of the excavation was M.A. Tomasz Tokarczyk. Area of 3.357 ha was excavated, where remains of the settlement dated to the Younger and Late Roman Period and Early Migration Period. 


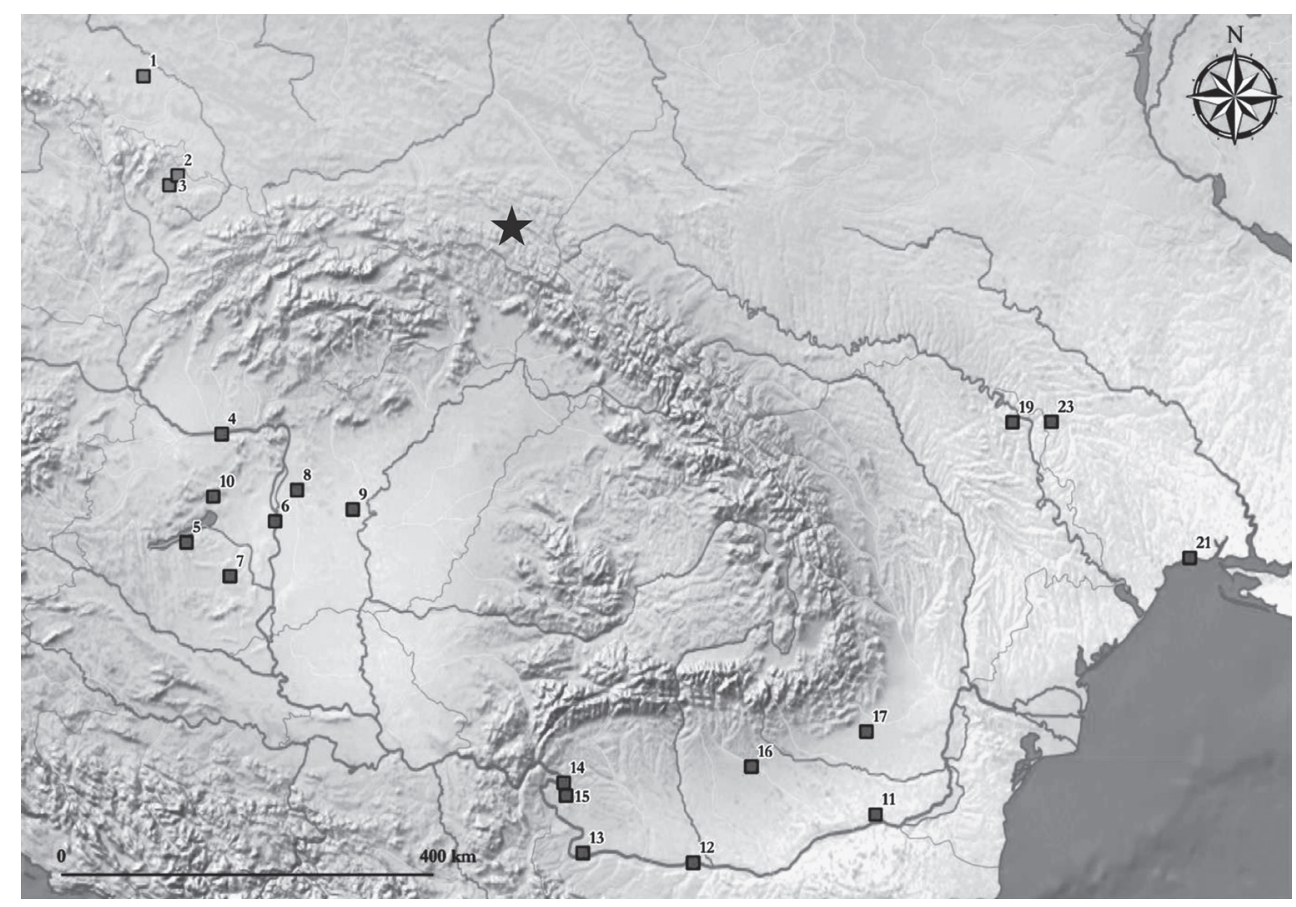

Fig. 3. Dispersion of the Hun-period cauldrons in Central and Eastern Europe (after: Masek 2017, 105, Fig. 25, with addition)

\section{DESCRIPTION AND COMPARISON WITH OTHER CAULDRONS}

The surface of the Hunnic cauldron fragment from Sanok is corroded. The piece's maximum dimensions are $3.6 \times 3.4 \mathrm{~cm}$. Its walls and ribs are 3 and $8 \mathrm{~mm}$ thick, respectively. The wall thickness of known cauldrons is varied, ranging from 2-3 $\mathrm{mm}$ to over $1 \mathrm{~cm}$ (cf.: Masek 2017, 98). Specimens with a wall thickness of 3 $\mathrm{mm}$, i.e. close to that of the cauldron fragment from site No. 59-60, have been uncovered in Şestaci, Moldova (Masek 2017, 92), Iža, Slovakia (Rajtár, Zábojnik 2010, 119, 125, Taf. 1. 3), and Razová, the Czech Republic (Tejral 2000, 151).

Given the small size and condition of the Sanok fragment, little can be said of the typological or stylistic characteristics of the cauldron it comes from, with the only noticeable feature being three parallel ribs. Such ribs are typical for many Hunnic cauldrons and can run either horizontally around the upper part of a vessel or vertically along its cylindrically elongated body. As the Sanok fragment is slightly deformed, it is impossible to determine the part of the vessel it comes from or the direction in which the ribs ran. Even if that was possible, the ribbing 
would still be insufficient to classify the vessel stylistically or to date it precisely ${ }^{3}$. However, it is a distinctive feature allowing the interpretation of fragmentary preserved piece (Fig. 4: 1 - 4). Such ornament is present on both cauldrons with rectangular handles, i.e. ones which are typologically simpler (Fig. 4: 8, 9, and see specimens from various sites in territory of modern Russia, e.g. Malai, Suncheleyevo, Soka (Osoka), or Verkhniy-Konets (Wosinsky 1891, 428, Fig. 2; Meanchen-Helfen 1973, 315, Fig. 45; Botalov 2009; Limberis, Marčenko 2011), and cauldrons with mushroom-shaped handles, (Fig. 4: 5-7, and e.g. from Várpalota, Törtel, Rádpuszta (Hungry), Nasyr-Kort (Russia), Desa (Romania), or Şestaci (Moldova) (Nestor, Nicolăescu-Plopşor 1937, Taf. 39: 3; Meanchen-Helfen 1973, 315, Fig. 43; Mamaev 2014, 63, Ryc. 4: 1-6; Masek 2017, 78, 94, 95, Fig. 6, 20, 21).

An ornament consisting of three parallel ribs features on Hunnic cauldrons both as their sole decorative element, e.g. on the specimens from Várpalota, Dunaújváros (Hungary), Perevolotchna Samara (Ukraine); Razová (the Czech Republic), or Iža (Slovakia) (Fig. 4: 7, 9; Alföldi 1932, fig. 6; Tejral 2000, 162, Obr. 1; Rajtár, Zábojnik 2010, 125, Taf. 1; Masek 2017, 79, 95, Fig. 7, 21), or in company with other moulded motifs present on the body, such as vertical lines ending with a circle, tassel motive, or tears/diagonal lines with a dot, (Fig. 4: 6, 8; and e.g. on the specimens from Rádpuszta, Törtel, Ócsa (Hungary), Nasyr-Kort, Soka (Russia), Desa (Romania), or Şestaci (Moldova) (Nestor, Nicolăescu-Plopşor 1937, Taf. 39: 3, Meanchen-Helfen 1973, 315, 317, Fig. 43, 45; Masek 2017, 77, 78, 94, Fig. 2, 6, 20; Mamaev 2014, 63, Ryc. 4: 1-6). Some specimens do not have triple ribbing at all and instead feature single lines, sometimes accompanied by other ornaments (see e.g. finds from Lipnyagova (Russia), Ivanovka (Ukraine) or Kapos Valley (Hungary) (Fettich 1953, pl. 36:4; Botalov 2009, Masek 2017, 96, Fig. 22). The cauldron from Jędrzychowice, Poland, has triple ribbing below the rim, with the ribs, however, spaced further apart from each other than in any other known specimen (Krause 1904). In conclusion, the ribbing motif is present on various cauldrons, both those from the Carpathian Basin and those from the Lower Danube region. It is, however, noteworthy that it is more common on vessels with mushroom-shaped handles. When present on cauldrons with rectangular handles, ribs are mostly confined to the handle, like e.g in specimen from Suncheleyevo in Russia (Botalov 2009). This may provide a hint at the recon-

\footnotetext{
${ }^{3}$ It must, however, be stressed that since most cauldrons and their fragments have been discovered by chance or in isolation, i.e. outside any archaeological context, they are particularly difficult to typologize or arrange in any chronological order. Only certain of their features, e.g. the shape of their handles or the proportion between their height and diameter, may be helpful in determining their development patterns and, indirectly, in their dating (cf.: Horhoiu, Diaconescu 1984, 100; Zaseckaja, Bokovenko 1994, 718, see Fig. 4; Horhoiu 1997, 132-134; Koch 2007, 287; Tejral 2010; Masek 2017, 90-94;). With no specific characteristics or stylistic features confining any of them to any well-defined periods, cauldrons at large are dated to the Hunnic expansion across Europe, i.e. the period between late 4th and mid 5th c. AD (por: Masek 2017, 94, see ibidem for references).
} 

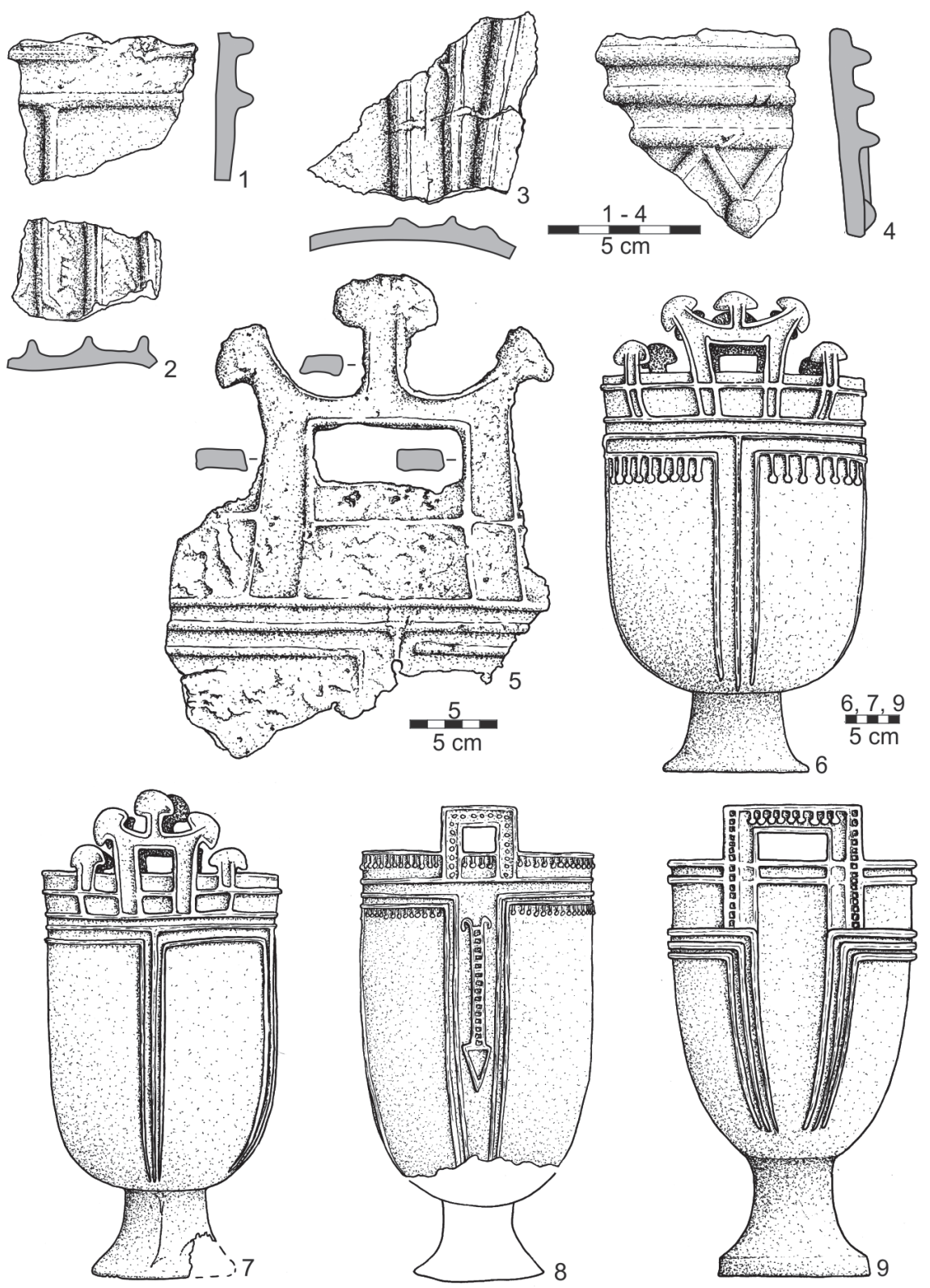

Fig. 4. Selected Hunnic cauldrons and their fragments from: 1 - 3 - Iža (after: 1 - 3: Rajtár, Zábojnik 2010, 125, Taf. 1: 1, 4, 5) ; 4 - Ócsa (after: Masek 2017, 77, Fig. 2); 5 - Razová (after: Tejral 2000, 162, Obr. 1); 6 - Khabaz (Tejral 2000, 164, Obr. 3: 1); 7 - Ioneşti (after: Tejral 2000, 164, Obr. 3: 3); 8 - Soka (Osoka) (after: Wosinsky 1891, 429, 3. ábra); 9 - Malai (after: Limberis, Marčenko 2011) 
struction of the Sanok cauldron, albeit one which should be treated with caution given that in general cauldrons with mushroom-shaped handles predominate among Hunnic cauldrons known to date and also include specimens without triple ribbing.

\section{THE METALLOGRAPHIC ANALYSES}

In light of the fact that the Sanok fragment is small and its archaeological context is not well-defined, a decision was taken to conduct metal testing on the artefact in order to prove the hypothesis that it was made of alloy with a high copper content and thus to further support its Hunnic interpretation. That assumption was in line with the generally accepted view, based on the available results of prior metal testing on several specimens, that Hunnic cauldrons had been cast from alloy with high cooper content (Mitrea 1961, 552; Garâinov 1980, 260; Barkóczy, May 2017, 121). The same is true for Sarmatian cauldrons, which may have a copper content of up to 99\% (Meanchen-Helfen 1973, 321). Studies of different cauldrons show, however, that that was not always the case. There are known specimens which are made of bronze, e.g. the one from Ioneşti. Its composition includes much less copper than that of other analysed cauldrons (Harhoiu, Diaconescu 1984, 116).

The cauldrons from Törtel, Várpalota, Kapos Valley, and Dunaújváros were subjected to comparative analyses, the purpose of which was to determine the places of production of these finds (Zimmer, Járó 1972, 122-125).

The studies regarding elemental composition established the by means of the energy dispersive X-ray fluorescence spectrometry (ED-XRF) using the spectrometer SPECTROMIDEX, as well as the microstructure observations complemented with elemental analysis in microregions by the means of the scanning electron microscope (SEM) Hitachi S- 3400N, equipped with EnergyDispersive X-ray Spectrometer (EDS) Thermo Noran were involved. Nondestructive research analyzes were engaged, without taking samples from the object. The material was prepared by mechanical removal of a surface fragment to expose the microstructure from under the corrosion layer. The results of the chemical composition were carried out in three areas: from both sides of the object (area A - on the outer side and area B - on the inner side) and for comparison in a corrosive layer (point C). Chemical composition analyzes are summarized in the table (Table 1). Average results for each measurement area are given.

The analysis shows that the vessel was made of lead bronze with a small tin addition. The average copper content is about $91 \%$, lead content is $6.5 \%$, while tin content is $1.5 \%$. The content of other determined elements is: $0.3 \%$ As, $0.2 \%$ $\mathrm{Ag}, 0.2 \% \mathrm{Ni}, 0.1 \% \mathrm{Zn}, 0.1 \% \mathrm{Fe}, 0.1 \% \mathrm{Sb}, 0.1 \% \mathrm{Bi}$. In this case, lead and tin are 
Table 1. Chemical composition analysis based on X-ray Fluorescence Spectroscopy analysis (wt.\%)

\begin{tabular}{|c|c|c|c|c|c|c|c|c|c|c|}
\hline \multirow{2}{*}{$\begin{array}{c}\text { Point } \\
\text { of measurement }\end{array}$} & \multicolumn{10}{|c|}{ Element (wt.\%) } \\
\cline { 2 - 12 } & $\mathrm{Fe}$ & $\mathrm{Ni}$ & $\mathrm{Cu}$ & $\mathrm{Zn}$ & $\mathrm{As}$ & $\mathrm{Ag}$ & $\mathrm{Sn}$ & $\mathrm{Sb}$ & $\mathrm{Pb}$ & $\mathrm{Bi}$ \\
\hline $\mathrm{A}$ & 0,04 & 0,18 & 91,03 & 0,13 & 0,29 & 0,11 & 1,19 & 0,08 & 6,87 & 0,07 \\
\hline $\mathrm{B}$ & 0,17 & 0,17 & 90,92 & 0,13 & 0,34 & 0,24 & 1,72 & 0,11 & 6,06 & 0,14 \\
\hline C (corrosion) & 1,26 & 0,13 & 62,40 & 0,23 & 1,06 & 0,90 & 7,14 & 0,32 & 26,43 & 0,15 \\
\hline
\end{tabular}

probably an intentional admixture, while elements such as As, $\mathrm{Sb}, \mathrm{Ag}, \mathrm{Ni}, \mathrm{Zn}, \mathrm{Fe}$ and $\mathrm{Bi}$ are present in copper ores.

Detailed microstructure analysis was performed in area A on the outer side of the cauldron. Images from the scanning microscope show surface topography at various magnifications (200-2000x) (Fig. 5).

The elemental composition in microareas was carried out at selected points. The distribution of elements was interpreted on the basis of EDS point analysis (Fig. 6, 7, Tab. 2,3) and presented on the basis of a map of element distribution (Fig. 8).

The matrix is made of copper, visible in the electron image as a gray uniform area marked with point 4 in the photo A-f (Fig. 6) and points 5, 6 and 7 in A-a (Fig. 7). At these points, copper concentration is the highest. In the solid solution tin is also present, with a maximum content of $1.9 \%$ at point $7 \mathrm{~A}-\mathrm{a}$ (Fig. 7, Tab. 3). Tin forms also low-melting point lead phases (light gray), visible in Fig. 6 in item 5 (Tab. 2). Lead, insoluble in copper, is present in the form of extensive irregular white precipitates, present in the entire volume of the alloy. It should be noted that the color of the precipitates is directly related to the average mass number of the phase, which clearly indicates the diversity of chemical composition when imaging using Backscatterd Electrons (BSE).

In the same area, a distribution map of the elements for copper, lead and tin was made (Fig. 8), confirming the earlier interpretation of the location of the elements in the examined fragment of the cauldron.

The distribution map of elements shows the dominant copper content, a small amount of tin in the solution $\alpha(\mathrm{Cu})$ and numerous irregular lead phases located at the grain boundaries.

Metallographic analyzes confirmed that the described fragment from Sanok is made of an alloy with high content of cooper, and therefore, in terms of used raw material, it does not deviate from other examined finds of this type. 

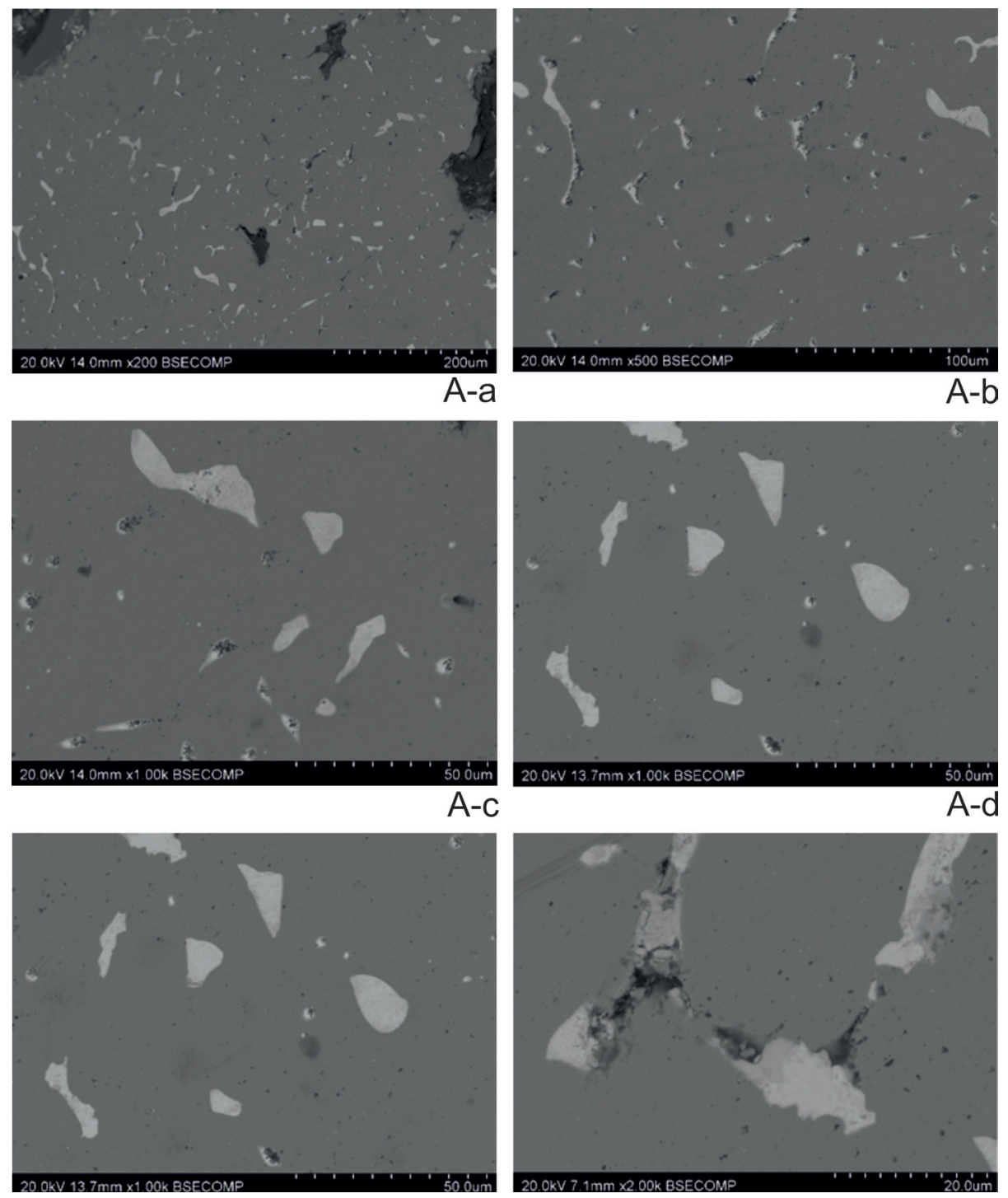

Fig. 5. SEM image using Backscatterd Electrons (BSE), mag. 200x (A-a), mag. 500x (A-b), mag. 1000x (A-c), mag. 1000x (A-d), mag. 1000x (A-e), mag. 2000x (A-f) 


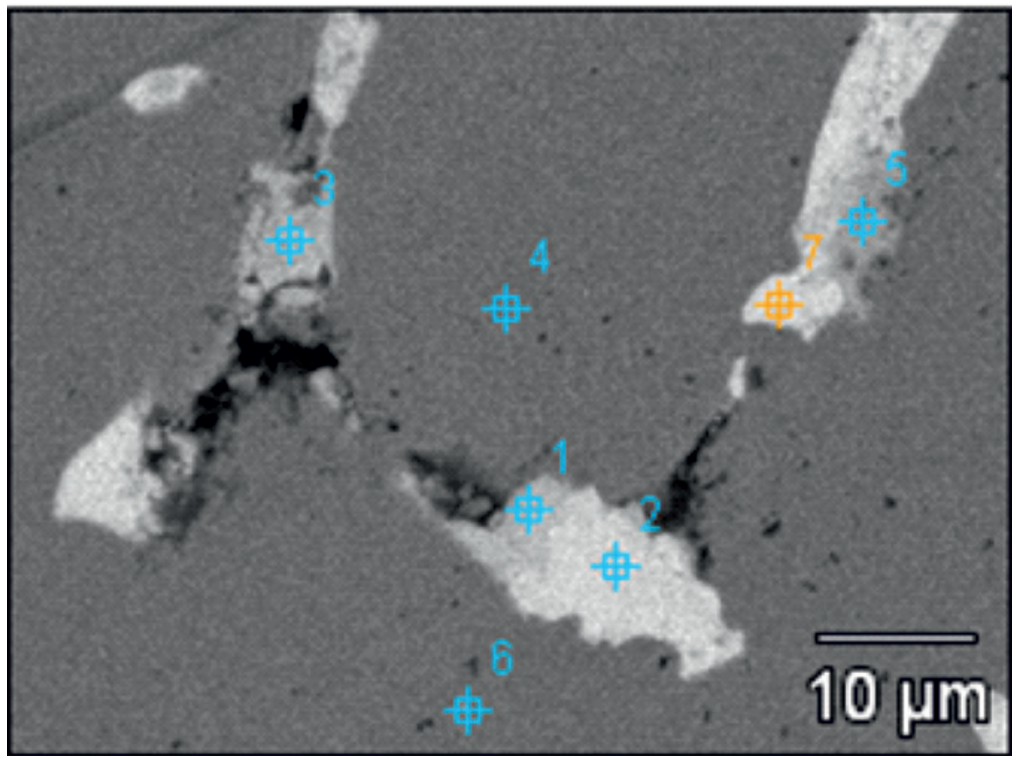

Fig. 6. SEM image using Backscatterd Electrons (BSE) with measurement points in area A-f, mag. 2000x

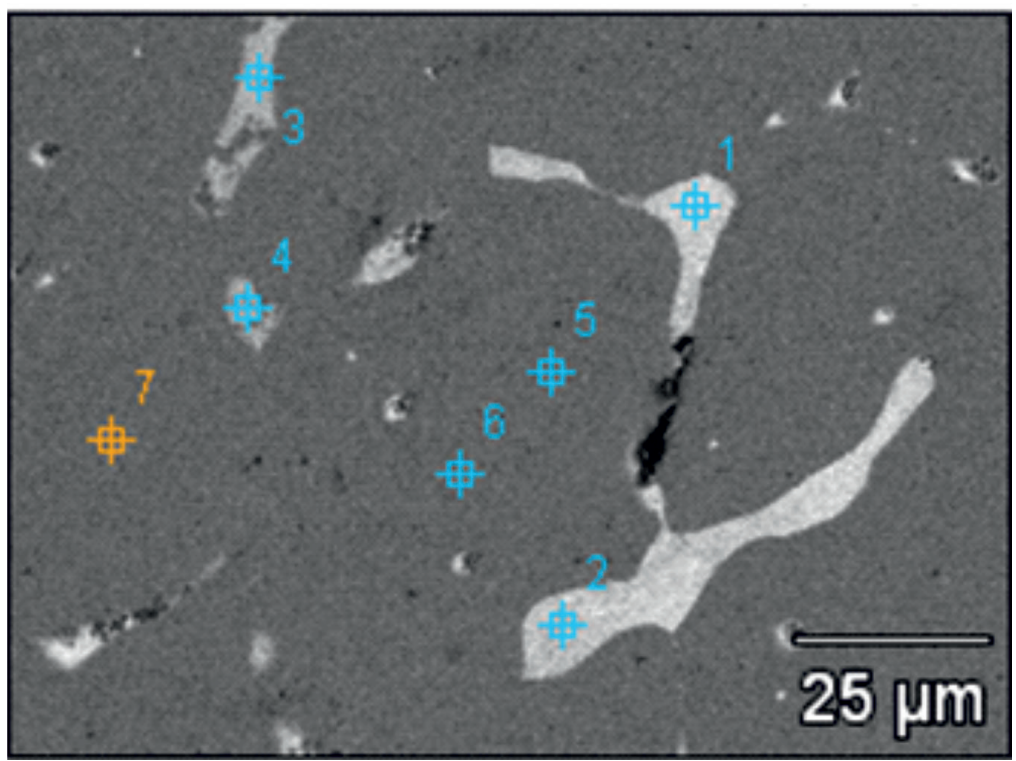

Fig. 7. SEM image using Backscatterd Electrons (BSE) with measurement points in area A-a, mag. 1000x 
Table 2. Chemical composition results in micro-areas based on EDS analysis in points marked in Fig. 6

\begin{tabular}{|c|c|c|c|}
\hline \multirow{2}{*}{$\begin{array}{c}\text { Point } \\
\text { of measurement }\end{array}$} & $\mathrm{Cu}$ & $\mathrm{Sn}$ & $\mathrm{Pb}$ \\
\cline { 2 - 4 } & 10.84 & - & 89.16 \\
\hline A-f_pt1 & 6.23 & - & 93.77 \\
\hline A-f_pt2 & 11.08 & - & 88.92 \\
\hline A-f_pt3 & 100.00 & - & - \\
\hline A-f_pt4 & 13.29 & 4.28 & 82.42 \\
\hline A-f_pt5 & 97.75 & 2.25 & - \\
\hline A-f_pt6 & 7.00 & - & 93.00 \\
\hline A-f_pt7 & &
\end{tabular}

Table 3. Chemical composition results in micro-areas based on EDS analysis in points marked in Fig. 7

\begin{tabular}{|c|c|c|c|}
\hline \multirow{2}{*}{$\begin{array}{c}\text { Point } \\
\text { of measurement }\end{array}$} & $\mathrm{Cu}$ & $\mathrm{Sn}$ & $\mathrm{Pb}$ \\
\cline { 2 - 4 } & 8.15 & - & 91.85 \\
\hline A-a_pt1 & 6.67 & - & 93.33 \\
\hline A-a_pt2 & 18.50 & - & 81.50 \\
\hline A-a_pt3 & 38.07 & - & 61.93 \\
\hline A-a_pt4 & 98.63 & 1.37 & - \\
\hline A-a_pt5 & 98.37 & 1.63 & - \\
\hline A-a_pt6 & 98.09 & 1.91 & - \\
\hline A-a_pt7 & &
\end{tabular}




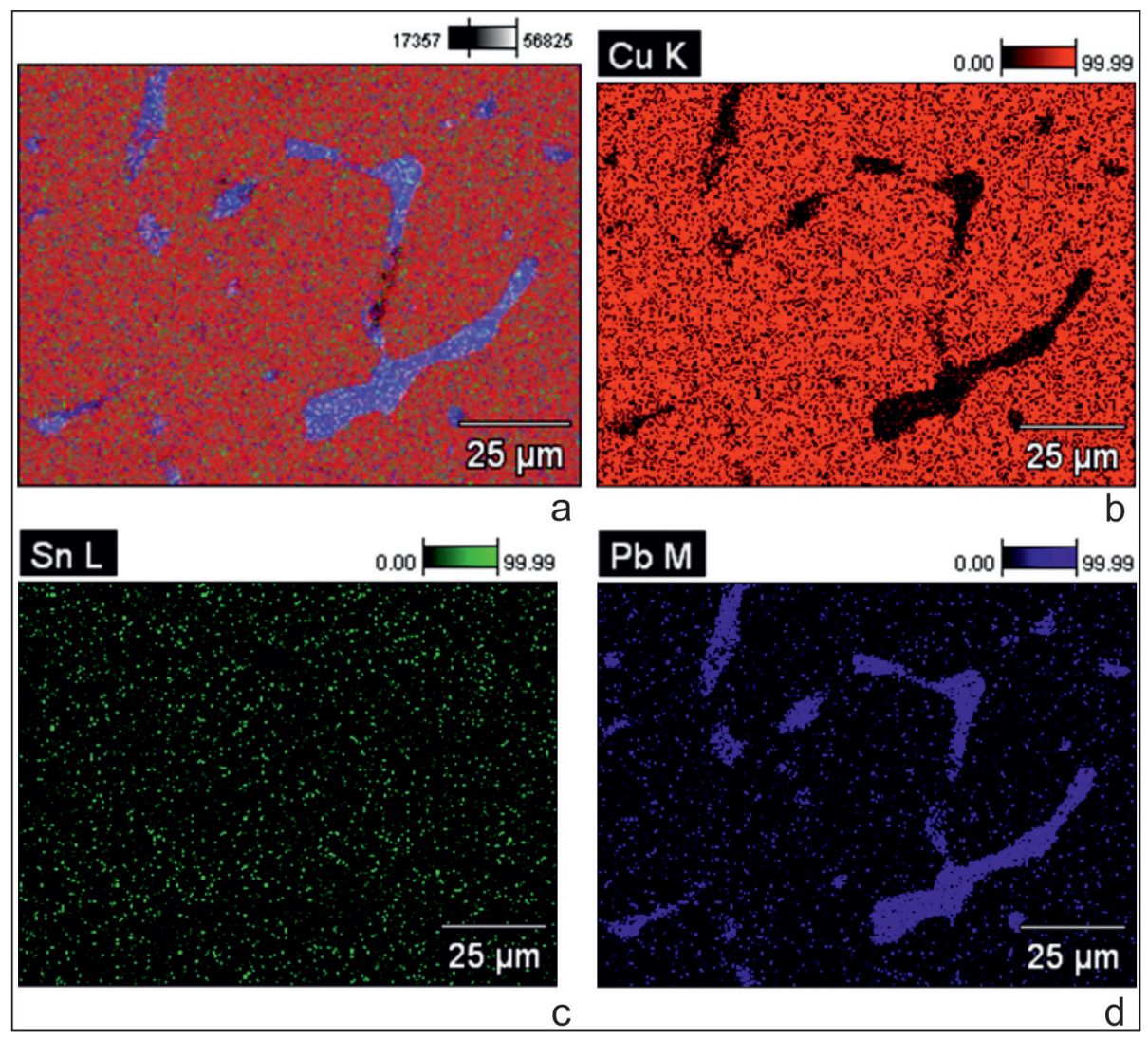

Fig. 8. Analysis of elements distribution in microregion: all elements incorporated in the image (a), $\mathrm{Cu}$ distribution (b), Sn distribution (c), Pb distribution (d)

\section{SANOK CAULDRON IN THE CONTEXT OF OTHER $4^{\mathrm{TH}}$ AND $5^{\mathrm{TH}}$ CENTURY FINDS DISCOVERED NORTH OF THE CARPATHIANS}

As has been mentioned above, the Sanok fragment is only the second artefact of its kind uncovered in Poland to date. Until its discovery, the single Hunnic cauldron from Poland was the completely preserved, and often cited, specimen from Jędrzychowice, county of Strzelin, Lower Silesia (Krause 1904, Kaczanowski, Rodzińska-Nowak 2013, 437, see ibidem for references). The piece from site No. 59-60 is also one of the very few artefacts that provide evidence of the relations between peoples who lived in the lands that today are part of Poland and the Hunnic empire (cf: Kaczanowski, Rodzińska-Nowak 2012, 2013; RodzińskaNowak 2016, 320-337; 2020). 
The recently discovered cauldron fragment may offer an important contribution to the discussion of the cultural landscape of the eastern part of the Polish Carpathians in the late $4^{\text {th }}$ and early $5^{\text {th }} \mathrm{c}$. AD. The Roman and Early Migration Period settlement patterns in the highland regions of the Polish Carpathians have been studied based on data yielded primarily by surveys and only a handful of excavation projects. What emerges from that research is a complex picture of the ancient cultures living in the area, which clearly merits further studies (cf.: Madyda-Legutko 1996, 2004, 2011, Madyda-Legutko, Tunia 2008; MadydaLegutko et al. 2013; Madyda-Legutko, Rodzińska-Nowak 2017). What is more, researchers' ability to establish a precise chronology of settlement in the Polish Carpathian highlands is constrained by a scarce archaeological record, which primarily includes pottery.

In the Beskids and the Slovakian highlands neighbouring them from the south, there have been discovered archaeological sites which are dated to the Late Roman and Early Migration Periods (cf: Pieta 1991; Madyda-Legutko, Tunia 2008, see ibidem for references). Their most notable examples include settlement sites in the Poprad river valley ${ }^{4}$ and the princley grave in Poprad, dated to the late 4th and early $5^{\text {th }}$ c. AD (Lau, Pieta 2014).

The archaeological record from the eastern part of the Polish Carpathians, however, includes few finds that can be reliably dated to the period in question (cf: Bulas 2019). According to the most recent data available, with the possible exception of the so far insufficiently researched settlement site in Lesko (Barłowska 1984) ${ }^{5}$, and partially excavated site No. 42 in Sanok, the settlement site discovered at site No. 59-60 in Sanok is the only one in the region that is certain to have been occupied in the late $4^{\text {th }} \mathrm{c}$. $\mathrm{AD}$ and also highly likely to continue to have been occupied in the early $5^{\text {th }} \mathrm{c}$. AD. Such dating is confirmed by various finds, including the fragment of a cauldron described above, a bucket-shaped vessel, and a range of vessels corresponding to pottery shapes from sites of the North Carpathian Group (Bulas et al. 2019). It is beyond question that the mentioned sites could not have been the only settlements in the eastern part of the Polish Carpathians that was occupied in that period, and our picture of human settlement in the region is likely to be largely incomplete owing to insufficient data. The existence of the dense settlemet pattern in the region dating to the Late Roman Period and Early Migration Period can be indirectly supported by the large number of the sites recognised during surface surveys, which yielded wheel-made pottery. It is important to underline that both newly excavated settlements in Sanok (site 42

${ }^{4}$ The most important results were yielded by research projects in Rytro and Moszczenica Wyżna, including pottery assemblages dated to the Early Migration Period (Madyda-Legutko, Tunia 1978, 1993, 2008, 229-235).

The site's chronology is uncertain as the archaeological record includes no precisely dating materials except for a piece of possibly Roman glass. 
and 59-60), dated to the Late Roman Period and Early Migration Period, are located close to each other. It can also demonstrate - at least in some degree - the dense settlement pattern in the region.

A late chronology of settlement sites located in the Polish Carpathian highlands have often been postulated before, including by analogy to the sites of the North Carpathian Group (Madyda-Legutko, Tunia 2008, 228-233). Although the archaeological record recovered so far contains few dating artefacts which could conclusively prove such hypothesis, both analogies drawn to sites in the other regions of the Carpathians and isolated finds from the eastern part of the Polish Carpathians make it highly plausible (Kotowicz, Fedyk 2008; Bulas 2019).

Settlement of the Upper San River Basin in the $5^{\text {th }} \mathrm{c}$. AD is confirmed by finds of late Roman coins (Bodzek 2009, 155-204; Bodzek, Pohorska-Kleja 2011; Bulas 2019; Bodzek et al. 2019), including two solidi, which are certain to have been minted in the $5^{\text {th }} \mathrm{c}$. $\mathrm{AD}$ and which both were discovered by chance, outside any welldefined archaeological context. The first one, a solidus of Emperor Valentinian III minted between 430 and $455 \mathrm{AD}$, was found in Prusiek, municipality of Sanok (Madyda-Legutko 1996, no. 586, 657; 2004, 81; Bodzek, Pohorska-Kleja 2011, 153-162). The second one was minted in Constantinople during the reign of Emperor Theodosius II, in 424-425 AD (Bodzek et al. 2019). Solidi dating to that period are also uncovered in the regions south of the Carpathians, which were controlled by the Huns (Bodzek 2009, 172, Masek 2017, 106-107, Fig. 26).

To a certain extent, indirect evidence of the cultural influence of the nomadic tribes on ancient communities living north of the Carpathians is offered by a hoard discovered in Świlcza (Gruszczyńska 1999). Based on stylistic and dendrochronological studies of the finds it contained, the deposit has been dated to 433+10 AD (Gruszczyńska 1999, 299; Kaczanowski, Rodzińska-Nowak 2012, 374 , see ibidem for references), i.e. the period when the dominance of the Hunnic empire over central Barbaricum was declining.

The aforementioned finds, in particular the Hunnic cauldron, which is likely to have been used by nomads in offering or other rituals, indicate that the regions located north of the Carpathians were penetrated by groups of Huns, perhaps in connection with the control exerted by them over one of the routes forming the Amber Road (Kaczanowski, Rodzińska-Nowak 2012, 374, see ibidem for references). It can definitely be concluded that ancient communities living in the San River Basin took part in the redistribution of goods obtained by the Hunnic empire as a result of its policies, including its expansion. Particularly strong evidence in support of this conclusion is offered by the aforementioned golden coins, which originally may have been part of tributes paid to the Huns in exchange for refraining from attacking the Roman Empire (Bodzek 2009, 175-176) and later redistributed among the nomads' Germanic allies (Bodzek et al. 2019). 
It is difficult to precisely determine the role that the communities living in the Upper San River Basin played in the historical events of the first half of the $5^{\text {th }} \mathrm{c}$. $\mathrm{AD}$ during the military and political expansion of the Huns. However, the cauldron whose fragment is described above seems to have been brought into settlement site No. 59-60 in Sanok by a group of Huns penetrating the region. The presence of Huns in southern Poland, in particular in the western part of Lesser Poland and Lower Silesia, has been well established on the basis of burial- and offering-related finds. The latest discoveries support the hypothesis formulated earlier (Maczyńska 1999, 32; 2005, 157; Kaczanowski, Rodzińska-Nowak 2013, 443-444) that south-eastern Poland was under direct, or at least indirect, cultural influence of the Hunnic empire as well.

\section{REFERENCES}

Alföldi A.

1932 Leletek a hun korszakbol es ethnikai szetvalasztasuk - Funde aus der Hunnenzeit und ihre ethnische Sonderung, Archaeologia Hungarica 9, Budapest.

Anke B.

1998 Studien zur reiternomadischen Kultur des 4. bis 5. Jahrhunderts, Beiträge zur Ur- und Frühgeschichte Mitteleuropas, vol.8, Weissbach.

Barkóczy P., May Z.

2017 APPENDIX: XRF AND SEM examination of the Hunnic cauldron fragment from Ócsa, [in:] A fresh look at Hunnic cauldrons in the light of a new find from Hungary, Z. Masek (ed.), Acta Archaeologica Academiae Scientiarum Hungaricae 68, Budapest, p. 121-126.

Barłowska A.

1984 Osada z późnego okresu wpływów rzymskich w Lesku, woj. Krosno, Materiały i Sprawozdania Rzeszowskiego Ośrodka Archeologicznego za lata 1976-1979, p. 51-101.

Bodzek J.

2009 Remarks on the inflow of Roman Coins into Southern Poland in the second half of the 4th and in the 5th centuries A.D, [in:] Byzantine Coins in Central Eu-rope between the 5th and 10th century, M. Wołoszyn (ed.) Moravia Magna. Seria Polona 3, Kraków, p. 155-204.

Bodzek J., Fedyk R., Kotowicz P.

2019 A Late-Roman Solidus Found at Pretuki (the Upper San Basin), Acta Archaeologica Carpathica 54, Kraków, p.269-284.

Bodzek J., Pohorska-Kleja E.

2011 Znalezisko solida Walentyniana III w Prusieku, gm. Sanok, woj. podkarpackie, Notae Numismaticae - Zapiski Numizmatyczne 6, Kraków, p. 153-162.

Botalov S. G.

2009 Gunny i Tûrki (istoriko-arheologičeskâ̂ rekonstrukciâ), Chelyabinsk.

Bulas J.

2019 Late Roman Period and early Migration period in upper San basin, Acta Archaeologica Carpathica 54, Kraków, p. 57-76. 
Bulas J., Mazurek M., Okońska M., Poradyło W.

2019 Wielokulturowe stanowisko 59-60 w Sanoku w świetle badań wykopaliskowych z lat 2017-2018, Raport 14, p. 55-81.

Fettich N.

1953 A szeged-nagyszeksosi hun fejedelmi sirlelet - La trouvaille de tombe princiere hunnique a Szeged-Nagyszeksos, Archaeologia Hungarica 32, Budapest.

Garâinov B. A.

1980 Gunnskoe pogrebenie v peŝere Ǔžnogo Priural'â, Sovetskaja Archeologija, 1980/4, p. 259-263.

Gruszczyńska A.

1999 Osada $z$ V wieku $w$ Świlczy na tle osadnictwa $w$ regionie rzeszowskim, [in:] Na granicach antycznego świata. Sytuacja kulturowa $w$ południowo-wschodniej Polsce $i$ regionach sqsiednich $w$ mtodszym okresie przedrzymskim $i$ w okresie rzymskim, S. Czopek, A. Kokowski (eds.), Rzeszów, p. 285-302.

Harhoiu R.

1997 Die fruhe Volkerwanderungszeit in Rumanien, Archeologia Romanica 1, Bukarest.

Harhoiu R., Diaconescu P.

1984 Hunnischer Kessel aus Muntenien, Dacia 28, p. 99-115.

Kaczanowski P., Rodzińska-Nowak J.

2012 Hunowie na ziemiach polskich, [in:] Próba podsumowania problematyki, Peregrinationes Archaeologicae in Asia et Europa Joanni Chochorowski Dedicatae, W. Blajer (ed.), Kraków, p. 371-378.

2013 The Huns on Polish lands: an attempt to summarise, [in:] A Nyíregyházi Jósa András Múzeum Évkönyve. Wandering and settled barbarians in the Carpathian region and neighboring areas (1st-5th cent,): new finds, new interpretations, Nyíregyháza, p. 431-450.

Koch A.

2007 Hunnische Kessel, [in:] Attila und die Hunnen, B. Anke (ed.), Stuttgart, p. 288-291.

Kovrig I. L.

1972 Hunnischer Kessel aus der Umgebung von Várpalota. Folia Archeologica 23, p. 95-121.

Kotowicz P. N., Fedyk R.

2008 Late-Roman Spatha from Lake Solinskie in Polańczyk, [in:] The turbulent epoch. New materials from the Late Roman Period and the Migration Period, B. Niezabitowska-Wiśniewska, M. Juściński, P. Łuczkiewicz, S. Sadowski (eds.), Monumenta Studia Gothica V, 2008, p. 113-117.

Krause E.

1904 Der Fund von Höckricht, Kreis Ohlau, Schlesiens Vorzeit in Bild und Schrift Lau N., Pieta K. Neue Folge 3, p. 46-50.

2014 Das Grab von Poprad-Matejovce in der Slowakei -Konstruktion, Ausstattun und Wiederöffnung einesfrühvölkerwanderungszeitlichen Kammergrabes, [in:] Kammergräber im Barbaricum.Zu Einflüssen und Übergangsphänomenen von der vorrömischen Eisenzeit bis in die Völkerwanderungszeit. A. Abegg-Wigg, N. Lau (eds.), Neumünster, Hamburg, p. 343-364.

Limberis N. Û., Marčenko I. I

2011 Pogrebeniâ èpohi velikogo pereseleniâ narodov $i$ rannegosrednevekov'â iz 
kurganov stepnogo Prikuban [in:] Poslanie ot Marka (sbornik, posvâŝennyj pamâti Marka Borisoviča Ŝkina), Stratum Plus 5, Kishinev, Saint-Pétersbourg, p. 417-441.

Madyda-Legutko R.

1996 Zróżnicowanie kulturowe polskiej strefy beskidzkiej $w$ okresie lateńskim $i$ rzymskim, Uniwersytet Jagielloński, rozprawy habilitacyjne, nr 304/1, Kraków.

2004 Polskie Karpaty wokresie późnolateńskim i w okresie wptywów rzymskich. Uwagi dotyczqce zróżnicowania kulturowego, [in:] Okres lateński i rzymski w Karpatach polskich, J. Gancarski (ed.), Krosno, p. 71-92.

2011 Drehscheibenkeramik aus dem Gebiet der polnischen Karpaten. Zur regionalen Differenzierung, [in:] Drehscheibentöpferei im Barbaricum - Technologietransfer und Professionalisierung eines Handwerks am Rande des Römischen Imperiums, J. Bemmann, M. Hegewisch, M. Meyer, M. Schmauder (eds.), Bonn: Institut für Vor- und Frühgeschichtliche Archäologie der Rheinischen Friedrich-WilhelmsUniversität. Bonn, p. 295-306.

Madyda-Legutko R., Rodzińska-Nowak J.

2017 Stan $i$ potrzeby badań nad osadnictwem okresu rzymskiego $w$ górnym biegu Sanu, [in:] Stan i potrzeby badań archeologicznych w Karpatach, J. Gancarski (ed.), Krosno, p. 429-450.

Madyda-Legutko R., Rodzińska-Nowak J., Zagórska-Telega J.,

2013 New data concerning the cultural situation in the basin of the Upper San River during the Roman Period, [in:] Proceedings of the international archaeological conference Wandering and Settled Barbarians in the Carpathian Region and Neighboring Areas (1st-5th cent.) New Finds, New Interpretations held in Nyíregyháza and Satu Mare October 11-14, E. Istvánovits, V. Kulcsár (eds.), p. 409-422.

Madyda-Legutko R., Tunia K.

1978 Wyniki badań stanowisk okresu rzymskiego w Moszczenicy Wyżnej, woj. Nowy Sacz, Acta Archaoelogica Carpathica 18, p. 113-149.

1993 Rytro. Karpacka osada z okresu wędrówek ludów, Zeszyty Naukowe Uniwersytetu Jagiellońskiego, Prace Archeologiczne 57, Kraków.

2008 Late Roman and Early Migration Period in Polish Beskid Mts., Carpathians Settlement Aspect, [in:] The turbulent epoch. New materials from the Late Roman Period and the Migration Period, B. Niezabitowska-Wiśniewska, M. Juściński, P. Łuczkiewicz, S. Sadowski (eds.), Monumenta Studia Gothica V, Lublin, p. 227-248.

Maenchen-Helfen O.

1973 The World of the Huns. Studies in Their History and Culture, Berkeley - Los Angeles.

Mamaev H. M.

2014 《Knâžeskoe» pogrebenie U g. Magas (Ingušetiâ) Kratkie soobŝeniâ IA RAN 234, p. 55-71.

Masek Z.

2017 A fresh look at Hunnic cauldrons in the light of a new find from Hungary, Acta Archaeologica Academiae Scientiarum Hungaricae 68, Budapest, p. 75-136.

Mączyńska M.

1999 Schytkowa faza kultury przeworskiej, [in:] Kultura przeworska, tom IV, A. Kokowski (eds.), Lublin, p. 25-53. 
2005 Zanik kultury przeworskiej, [in:] Archeologia o poczatkach Stowian, Kaczanowski P., Parczewski M. (eds.), Kraków, 157-163.

Mitrea B.

1961 Beitrage zum Studium der hunnischen Altertumer - Zwei neue Kesselgriffe aus Dem sudlichen Muntenien, Dacia 5, p. 549-558.

Nestor J., Nicolăescu-Plopşor C. S.

1937 Hunnische Kessel aus der Kleinen Walachei, Germania 21, p. 178-182.

Pieta K.

1991 The North Carpathians at the beginning of the Migration Period, Antiquity 65, p. 376-387.

Rajtár J., Zábojník J.

2010 Fragmente von hunnischen Kesseln in Iža, [in:] Ĭntre Stepă şi Imperiu. Studii in onoarea lui Radu Harhoiu /Between the Steppe and the Empire. Archaeological Studies in honour of Radu Harhoiu at 65th Anniversary, A. Măgureanu, E. Gall (ed.), Bucureşti, p. 119-125.

Rodzińska-Nowak J.

2016 Societies in the lands of Poland, from 350 AD until 500 AD, [in:] The Past Societies. Polish lands from the first evidence of human presence to the Early Middle Ages 4: 500 BC - 500 AD, A. Rzeszotarska-Nowakiewicz (ed.), Warszawa, p. 308-315.

2020 Early Migration Period Nomadic Finds, [in:] The Migration Period between the Oder and the Vistula, A. Bursche, J. Hines, A. Zapolska (eds.), Leiden-Boston, p. 370-410.

Tejral J.

2000 Novèe poznátky $k$ nalezu „hunského” kotle z Razové, Acta historia et museologica Wosinsky M.

1891 A kaposvolgyi nepvandorlas kori ust [The cauldron from the Migration period in the Kapos valley], Archaeologiai Értesítő 11, Budapest, p. 427-431.

Zaseckaja I. P., Bokovenko N. A.

1994 The origin of Hunnish cauldrons in East-Europe, [in:] The Archaeology of the Steppes. Methods and Strategies. Papers from the International Symposium held in Naples 9-12 November 1992, B. Genito (ed.), Napoli, p. 701-724.

Zimmer K., Járó M.

1972 Spektrographische Untersuchungen von hunnischen Kesseln [in:] Kovrig I. L., Hunnischer Kessel aus der Umgebung von Várpalota, Folia Archeologica 23, p. $122-125$. 
Addresses of the Authors

\section{Magdalena Okońska-Bulas}

Institute of Archaeology

Jagiellonian University in Kraków

ul. Gołębia 11

31-007 Kraków, Poland

lena.okonska@wp.pl

ORCID ID: 0000-0002-0429-6668

\section{Mirosław Mazurek}

Pracowania Archeologiczna

Mirosław Mazurek

\section{Jan Bulas}

Fi Projekt Jan Bulas

Kraków, Poland

bulas.jan@gmail.com

ORCID ID: 0000-0003-2842-0210

\author{
Aldona Garbacz-Klempka \\ Faculty of Foundry Engineering \\ The Historical Layers Research Centre \\ AGH University of Science and Technology \\ ul. Reymonta 23 \\ 30-059 Kraków, Poland \\ ORCID ID: 0000-0001-8417-6131
}

Małgorzata Perek-Nowak

Faculty of Foundry Engineering

The Historical Layers Research Centre

Faculty of Non-ferrous Metals

AGH University of Science and Technology

Al. Mickiewicza 30

30-059 Krakow, Poland

ORCID ID: 0000-0003-0323-1624 
